Diabetologia $10,501-508(1974)$

(C) by Springer-Verlag 1974

\title{
Studies in the Diabetic Chinese Hamster: Light Microscopy and Autoradiography of Pancreatic Islets*
}

\author{
A. A. Like, G.C. Gerritsen, W.E. Dulin and P. Gaudreau \\ Elliott P. Joslin Research Laboratory, Joslin Diabetes Foundation, Inc., Department of Pathology, Peter Bent \\ Brigham Hospital, Harvard Medical School, Boston, Mass., and Upjohn Company, Kalamazoo, Mich., USA
}

Summary. Light microscopic and autoradiographic studies were performed in normal genetic nondiabetic and diabetic Chinese hamsters after the administration of thymidine ${ }^{3} \mathrm{H}$ and correlated with levels of blood glucose (BG) and plasma insulin (IRI). Pancreatic islets of normal hamsters contained well granulated beta cells; rare islet cells incorporated thymidine ${ }^{3} \mathrm{H}$ and the IRI/BG ratio $(\mathrm{I} / \mathrm{G})$ was $=1.91$. Recent onset diabetics revealed hyperglycemia and hyperinsulinemia $(\mathrm{I} / \mathrm{G}=1.97)$, beta cell degranulation and increased islet cell labelling. With progression of diabetes, I/G ratios decreased (Non-ketotic animals: 1.08, Ketotic hamsters: 0.17 ), beta cell numbers declined and islet labelling was infrequent. Hamsters with spontaneous remission from diabetes showed normoglycemia, hyperinsulinemia $(I / G=2.84)$ and beta cell hyperplasia. Glucocorticoid administration to normal hamsters induced marked BG elevations, beta cell hyperplasia and increased thymidine- ${ }^{3} \mathrm{H}$ incorporation. The absence of increased beta cell labelling among most diabetics treated with glucocorticoids may be a manifostation of a genetically defined defect of beta cell replication that is in part responsible for the declining beta cell mass and insulin synthetic capacity of the diabetic Chinese hamsters.

Key words: Chinese hamster, Cricetulus griseus, spontaneous diabetes, pancreatic islets, islets of Langerhans, beta cell mitosis, beta cell hyperplasia, autoradiography, insulin, diabetes remission, adrenal glucocorticoid.
In 1959 , the occurrence of diabetes mellitus in a colony of Chinese hamsters was reported by Meier and Yerganian [1]. In this and subsequent publications, a number of unique characteristics were documented. The diabetic syndrome is believed to be the result of a polygenic inheritance $[2,3]$ with at least four genes involved. When any two of these genes are homozygous recessive, the animals become diabetic [3]. The syndrome is characterized by hyperphagia [4, 5], early but variable onset of hyperglycemia and glycosuria and the unique absence of obesity $[1,7]$. Hepatic and renal gluconeogenesis are elevated [6] and peripheral adipose tissue and skeletal muscle are normally responsive to insulin in vitro [7]. With the progression of the syndrome, plasma levels and extractable pancreatic content of insulin are decreased [7] and life expectancy is reduced among the more severely diabetic animals. Morphological studies of the pancreatic islets reveal alterations primarily limited to the beta cells, with degranulation, glycogen infiltration, degeneration, necrosis and eventually decreased cell numbers $[1,89,10]$. Alpha cells become relatively more numerous and are reportedly abnormal in ketotic animals [11].

In the course of previous studies of the Diabetic Mutant Mice $[12,13,14]$ and a subsequent analysis of other models of diabetes in laboratory animals, it was suggested that the course and outcome of many diabetic syndromes might be a function of the ability of the organism to produce new beta cells

* Supported in part by USPHS Grants AM-15193, K4-AM-7394, AM-05077, the Joslin Diabetes Foundation, Inc., and the Upjohn Company, Kalamazoo, Mich. during periods of hyperglycemic stress [15]. The disease is therefore most severe and eventually lethal among the Chinese hamsters $[1,8]$ and the C57BL/Ks - $\mathrm{db} / \mathrm{db}$ mice $[12,16,17]$, animals in which a progressive diminution of the beta cell mass eventually leads to insulin insufficiency. In contrast, laboratory models such as the C57BL/6J-ob/ob mice $[18,19]$ and the C3Hf X I F (Wellesley hybrid) mice $[20,21]$ have greatly enlarged pancreatic islets, with increased numbers of beta cells, an enhanced insulin synthetic capacity and a more mild syndrome. Hence, the recognition within the Upjohn colony of Chinese hamsters of the occurrence of spontaneous remission among severely diabetic animals provided us with the opportunity to test our hypothesis in a most meaningful way. Characterized by the early onset (2-4 months of age) of hyperglycemia and glycosuria, these hamsters manifested a nonketotic diabetic syndrome for 3 to 4 months followed by the gradual disappearance of glycosuria and the return of glycemic levels to normal. Although the glucose tolerance tests were not completely normal, the remission appeared to be permanent and the hamsters remained aglycosuric and normoglycemic indefinitely. Also identified in the Upjohn colony was yet another group of diabetic hamsters which displayed an erratic clinical course with hyperglycemia and glycosuria of variable severity, as well as periods of normoglycemia and aglycosuria. If our hypothesis is correct and if the number of functioning beta cells indeed determines the course and outcome of the diabetic syndrome, one would expect the pancreatic beta cell mass of animals in remission and possibly those with an erratic syn- 
drome to be larger than the beta cell mass of more severely diabetic hamsters. One would anticipate also that the levels of circulating insulin would be higher in these two groups of animals. To test these expectations, the morphologic appearance of the pancreatic islets was studied and correlated with blood glucose and plasma insulin levels in normal hamsters and in the several groups of diabetic hamsters, including animals after spontaneous remission and with the erratic syndrome. Furthermore, in an attempt to determine whether diabetic hamster beta cells could be induced to undergo mitotic division, we administered large quantities of a potent adrenal glucocorticoid to normal and diabetic animals. The rationale for the utilization of this classical diabetogenic agent rested on a large number of early studies which reported the induction by corticosteroids of hyperglycemia and beta cell hyperplasia in many normal laboratory animals [22], including nondiabetic Chinese hamsters $[23,24]$.

In this paper we shall present the results of lightmicroscopic studies of the pancreatic islets of normal Chinese hamsters and the changes observed in the islets of spontaneously diabetic animals. The results of autoradiographic studies after thymidine- ${ }^{3} \mathrm{H}$ administration will also be reported in untreated hamsters and following the injection of normal and diabetic hamsters with methylprednisolone acetate (DepoMedrol ${ }^{1}$ ), a potent adrenal glucocorticoid. A companion paper [25] describes the results of electron microscopic examinations of the islets of untreated, normal and diabetic hamsters. Since physiological studies were also performed, structural-functional correlations will be presented when possible.

\section{Material and Methods}

A total of 111 Chinese hamsters (33 normal and 78 diabetic) were studied. 74 were obtained from the Upjohn colony and the remaining 37 (22 normal and 15 diabetic) were purchased from the colony maintained by Dr. George A. Yerganian (Children's Hospital Medical Center, Boston, Mass.) 54 hamsters (22 normal and 32 diabetic) received 4 to 6 intramuscular injections, $4 \mathrm{mgm}$ each, of methylpreơnisolone acetate over a period of 7 to 14 days. Of the remaining untreated animals, 52 with adequate blood glucose and plasma insulin data, and all derived from the Upjohn colony, provided the data for the physiological studies. They were divided into six groups according to the severity of the syndrome: Normal6 hamsters, 11-18 months of age, consistently aglycosuric and derived from parental lines that have been Testape negative for at least 10 to 15 genera-

\footnotetext{
1. The Upjohn Company, Inc., Kalamazoo, Michigan, USA

2 Testape ${ }^{\circledR}$ - Eli Lilly \& Co., Indianapolis, Indiana,
}

tions of continuous brother sister matings. Recent onset- 9 hamsters, $3 \frac{1}{2}-5$ months of age, with diabetes of less than 4 months duration. Non-ketotic- 9 hamsters, 11-21 months of age, with consistent $4+$ glycosuria but without ketonuria. Ketotic- 7 hamsters, 9-18 months of age, with consistent $4+$ glycosuria and ketonuria (Ketostix ${ }^{3}$ ). Erratic-type 12 hamsters $10-$ 23 months of age, with alternating periods of hyperglycemia with glycosuria and normoglycemia. Hamsters in remission- 9 hamsters, 9-21 months of age, with early onset of glycosuria (4+Testape) and hyperglycemia which persisted for periods of $3-4$ months prior to the gradual disappearance of glycosuria and the return of glycemic levels towards normal. The hamsters were allowed free access to Purina mouse breeder pellets (lipid content 12\%) and water. Non fasting blood glucose (BG) [26] and plasma immunoreactive insulin (IRI) [27], were measured at intervals on samples obtained by orbital puncture. Thymidine- ${ }^{3} \mathrm{H}^{4}$, $10-20$ microcuries per gram body weight was given intraperitoneally two hours prior to sacrifice, at which time the pancreata were removed for morphologic study and a complete autopsy performed. For light microscopy and autoradiography, the pancreas with an attached segment of duodenum was fixed in Bouin's solution. For conventional light microscopy, paraffin embedded sections were stained with H \& E, Aldehyde fuchsin [28] and PTAH. [29]. For autoradiography, paraffin sections were mounted on gelatin coated slides. Deparaffinization was followed by exposure to $0.5 \%$ periodic acid and the slides were subsequently washed, dehydrated and coated with Ilford L-4 emulsion. After exposure for periods of $1-5$ weeks in Drierite containing light-tight boxes, stored at $4^{\circ} \mathrm{C}$, the emulsion was developed and the slides placed in Schiff's reagent for the completion of the PAS stain.

Results

\section{Physiologic Studies}

Blood glucose (BG) and plasma immunoreactive insulin (IRI) values for the untreated normal and diabetic Chinese hamsters are shown in Fig. 1 and document the progressive severity of the diabetic syndrome. Mean BG was significantly higher than normal in all diabetic animals. Mean BG of hamsters in remission, however, was significantly lower than in other diabetic hamsters with the exception of the recent onset group. Plasma IRI of hamsters with recent onset diabetes was significantly elevated, but with progression of the syndrome, absolute levels of IRI returned to normal in non-ketotic, and erratic syndrome hamsters and were significantly decreased

3 Ketostix ${ }^{\circledR}-$ Ames Co., Inc., Elkhart, Indiana, USA

4 Thymidine-methyl- ${ }^{3} \mathrm{H}$, specifie activity 15 euries/ mMole, New England Nuclear Co. 
among the ketotic type. Mean plasma IRI was, however, significantly elevated among animals in remission. Even more graphic were the alterations in the insulin/ glucose $(\mathrm{I} / \mathrm{G})$ ratios which were significantly below normal among the more severely diabetic animals but returned to or were greater than normal among hamsters in remission.

Hyperglycemia was induced in $93 \%$ of normal hamsters receiving glucocorticoid injections, with significant elevations recorded after 3-4 days, and extreme elevations (ranging from $338-550 \mathrm{mgm} \%$ ) noted at 7 and 14 days. BG levels of spontaneously diabetic hamsters were not further increased by Depo-Medrol injections. Non fasting lipemic plasma was, however, observed frequently, but without an associated increase of ketonemia or ketonuria. Body weights of glucocorticoid injected animals decreased approximately $12.5 \%$ (with a range of $6-27 \%$ ).

43 of the animals died or became ill and were discarded during the course of the experiments. 18 of this group (4 normal and 14 diabetics) had received Depo-Medrol.

Chinese Hamsters

\begin{tabular}{llll}
\hline & $\begin{array}{l}\text { Blood } \\
\text { Glucose } \\
(\mathrm{mgm} \%)\end{array}$ & $\begin{array}{l}\text { Plasma IRI } \\
\mu U / m l\end{array}$ & $\begin{array}{l}\text { IRI/Glucose } \\
\text { Ratio }^{\mathrm{b}}\end{array}$ \\
\hline $\begin{array}{l}\text { Normal } \\
\quad(6)\end{array}$ & $103 \pm 2$ & $235 \pm 27$ & $1.91 \pm 0.31$ \\
$\begin{array}{c}\text { Recent } \\
(9)\end{array}$ & $226 \pm 17^{\mathrm{a}}$ & $418 \pm 74^{\mathrm{a}}$ & $\mathbf{1 . 9 7} \pm 0.39$ \\
$\begin{array}{c}\text { Non-Ketotic } \\
\quad(9)\end{array}$ & $325 \pm 32^{\mathrm{a}}$ & $293 \pm 70$ & $1.08 \pm 0.30^{\mathrm{a}}$ \\
$\begin{array}{c}\text { Ketotic } \\
\quad(7)\end{array}$ & $349 \pm 24^{\mathrm{a}}$ & $53 \pm 12^{\mathrm{a}}$ & $0.17 \pm 0.05^{\mathrm{a}}$ \\
$\begin{array}{c}\text { Erratic } \\
\quad(12)\end{array}$ & $290 \pm 30^{\mathrm{a}}$ & $238 \pm 24$ & $0.94 \pm 0.16^{\mathrm{a}}$ \\
$\begin{array}{c}\text { Remission } \\
(9)\end{array}$ & $176 \pm 11^{\mathrm{a}}$ & $454 \pm 105^{\mathrm{a}}$ & $2.84 \pm 0.78$ \\
\hline
\end{tabular}

Fig. 1. Blood glucose, plasma immunoreactive insulin (IRI) and IRI/Glucose ratios of normal and diabetic Chinese hamsters. Values are means \pm S. F.M. Numbers of hamsters are in parentheses. - a) Significantly different $(p<0.05)$ than corresponding value of normal hamsters. b) Values indicated are means of individual ratios \pm S.E.M.

\section{Conventional Histologic Studies}

Normal Hamsters. The light-microscopic appearance of the pancreatic islets of the normal Chinese hamsters could not be distinguished from those of other nondiabetic rodents studied in this laboratory $[12,21]$. Although the diameter of individual islets varied considerably, most were round or oval in outline (when viewed in two dimensions) and scattered throughout the exocrine parenchyma. Aldehyde fuchsin stained preparations revealed the centrally located, well granulated beta cells, surrounded by a narrow rim of aplha cells (Fig. 2a). Although the number of alpha cells was somewhat varied from islet to islet, they were almost without exception located at the periphery of the islet where they separated the underlying beta cells from the adjacent exocrine tissue of the pancreas. It should be emphasized, however, that the peripheral alpha cell "mantle" was sometimes incomplete, with small groups of beta cells apparently in spatial contact with the adjacent exocrine pancreas.

Diabetic Hamsters. The earliest alteration in islet morphology, the presence of beta cell degranulation, was observed among recent onset diabetics in association with increased levels of plasma IRI. Although variable in degree and uniformity, most islets revealed incomplete beta cell degranulation as well as increased beta cell size (Fig. 2b). Alpha cells were still localized at the periphery of the islets. With further progression of the diabetic syndrome, beta cell degranulation was more pronounced, alpha cells were frequently located within the interior of the islet as well as at the periphery, and beta cell vacuolization noted (Fig. 2c, d, e). Islet size and appearance were variable within individual animals and from animal to animal, making it virtually impossible to distinguish non-ketotic hamsters and those with the erratic syndrome from one another with certainty (Fig. 2c, e). Among ketotic hamsters however, identifying features were discernible within many islets and correlated well with the observed reduction in plasma IRI and the $I / G$ ratio. The overall size of the islets was decreased, beta cell numbers diminished and degranulation more extensive, beta cell vacuolization was pronounced (Fig. 2d) and intra-islet fibrosis frequently noted. Finally, alpha cells were proportionately increased in number and occasional small islets were composed predominantly of alpha cells. In striking contrast was the usual appearance of the islets among hamsters that had undergone spontaneous remission from diabetes. Although there was moderate variability from islet to islet, most appeared larger than those of normal and diabetic animals and were composed predominantly of partially degranulated beta cells (Fig. 2f). Cytoplasmic vacuolization and fibrosis were not apparent.

The exocrine pancreas of normal and diabetic hamsters could not be differentiated.

\section{Animals Receiving Glucocorticoids}

Normal Hamsters. Beta cell degranulation was widespread among non-diabetic hamsters treated with Depo-Medrol (Fig. 3a). Beta cell size and number were increased, showing variation in nuclear size, infrequent mitoses, and fine cytoplasmic vacuolization. The characteristic oval or round islets usually found in the untreated hamster were obscured by irregular collections of cells often arranged in nodular aggregates protruding into the adjacent exocrine parenchyma. Although the above observations were somewhat variable from animal to animal, the degree of beta cell degranulation and the magnitude of the islet 

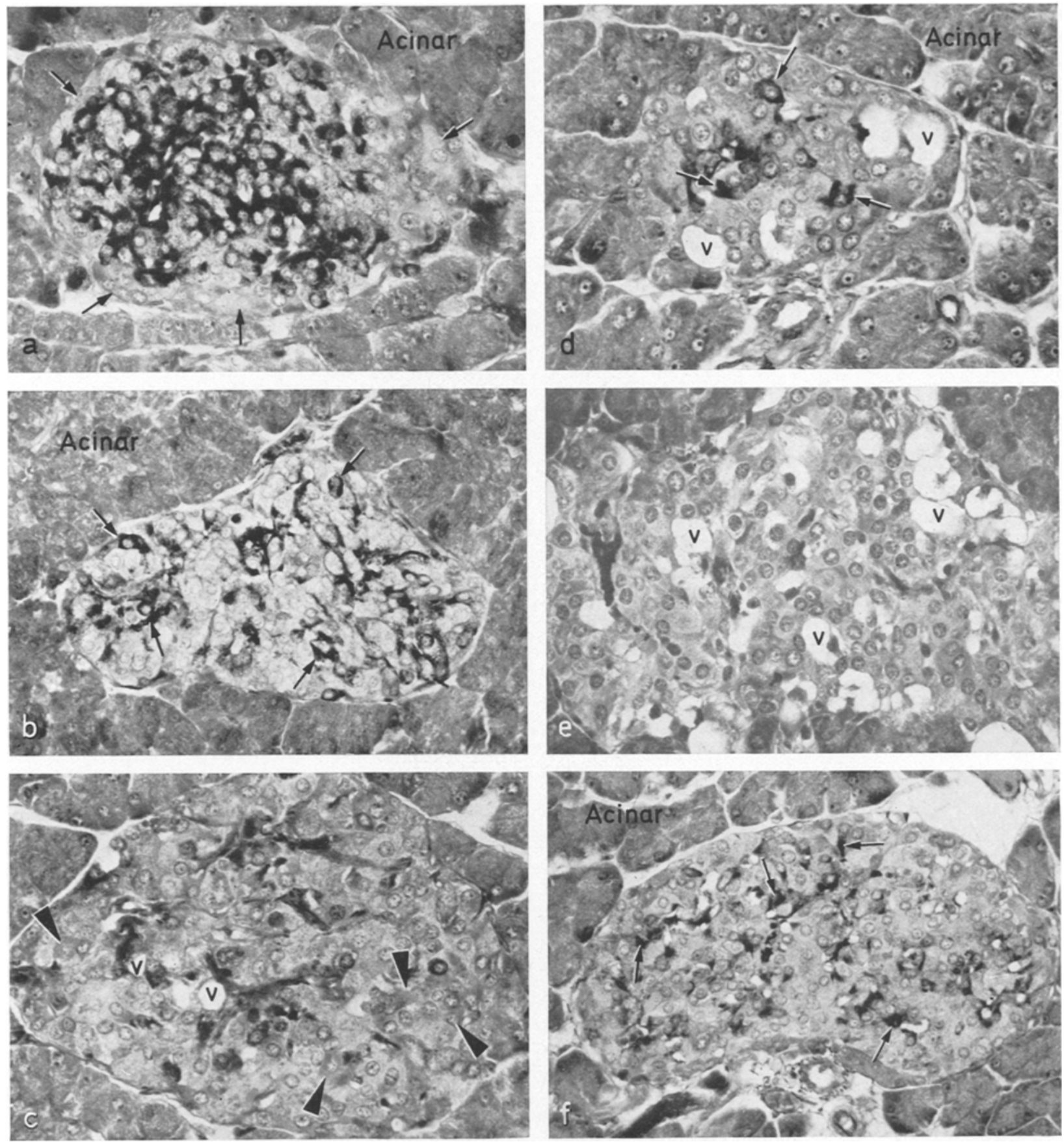

Fig. 2a-f. Pancreatic islets of Chinese hamsters. Tissue fixed in Bouin's solution and sections stained with aldehyde fuchsin. a) Normal Chinese hamster. The deeply staining well granulated beta cells (black in photograph) are characteristic of normoglycemic animals. Peripheral alpha cells are indicated by arrows and separate most of the beta cells from the adjacent acinar tissue. Approximately $380 \times$. b) Recent onset diabetic Chinese hamster with hyperglycemia and hyperinsulinemia. Beta cell degranulation is incomplete. A moderate number of beta cells contain aldehyde fuchsin positive granules (arrows). Approximately $294 \times$. c) Non-ketotic hamster. Beta cell degranulation is almost complete and several cells appear vacuolated $(V)$ due to dissolution of cytoplasmic glycogen. Alpha cells (arrow heads) are no longer limited to islet periphery. Approximately $400 \times$. d) Ketotic hamster with pronounced hyperglycemia and low plasma IRI. Islet is decreased in size with few remaining degranulated and vacuolated beta cells (v). Rare Beta cells contain aldehyde fuchsin positive granules (arrows). Approximately $488 \times$. e) Hamster with the erratic syndrome. Degranulated and vacuolated (V) beta cells. Islet appearance is extremely variable. Approximately $360 \times$ f) Hamster in spontaneous remission with normoglycemia and hyperinsulinemia. Enlarged islet contains increased number of beta cells, many of which are degranulated. Aldehyde fuchsin positive cells are visible (arrows). Approximately $288 \times$ 
enlargement could be correlated directly with the magnitude and duration of hyperglycemia in the individual hamsters. Alpha cell alterations were not observed.

Diabetic Hamsters. The islets of the very small number of surviving Depo-Medrol injected spontaneously diabetic animals could not be distinguished with confidence from those of non-injected controls. Since variability of islet appearance among the seriously afflicted spontaneously diabetic hamsters is striking, it is conceivable that subtle glucocorticoid induced alterations might not have been apparent because of the small sampling of injected animals studied.

\section{Autoradiographic Studies}

General Comments. The terms labelled cell and labelling are used interchangeably and denote the presence of a cluster of black silver grains in the photographic emulsion overlying the cell nucleus. The
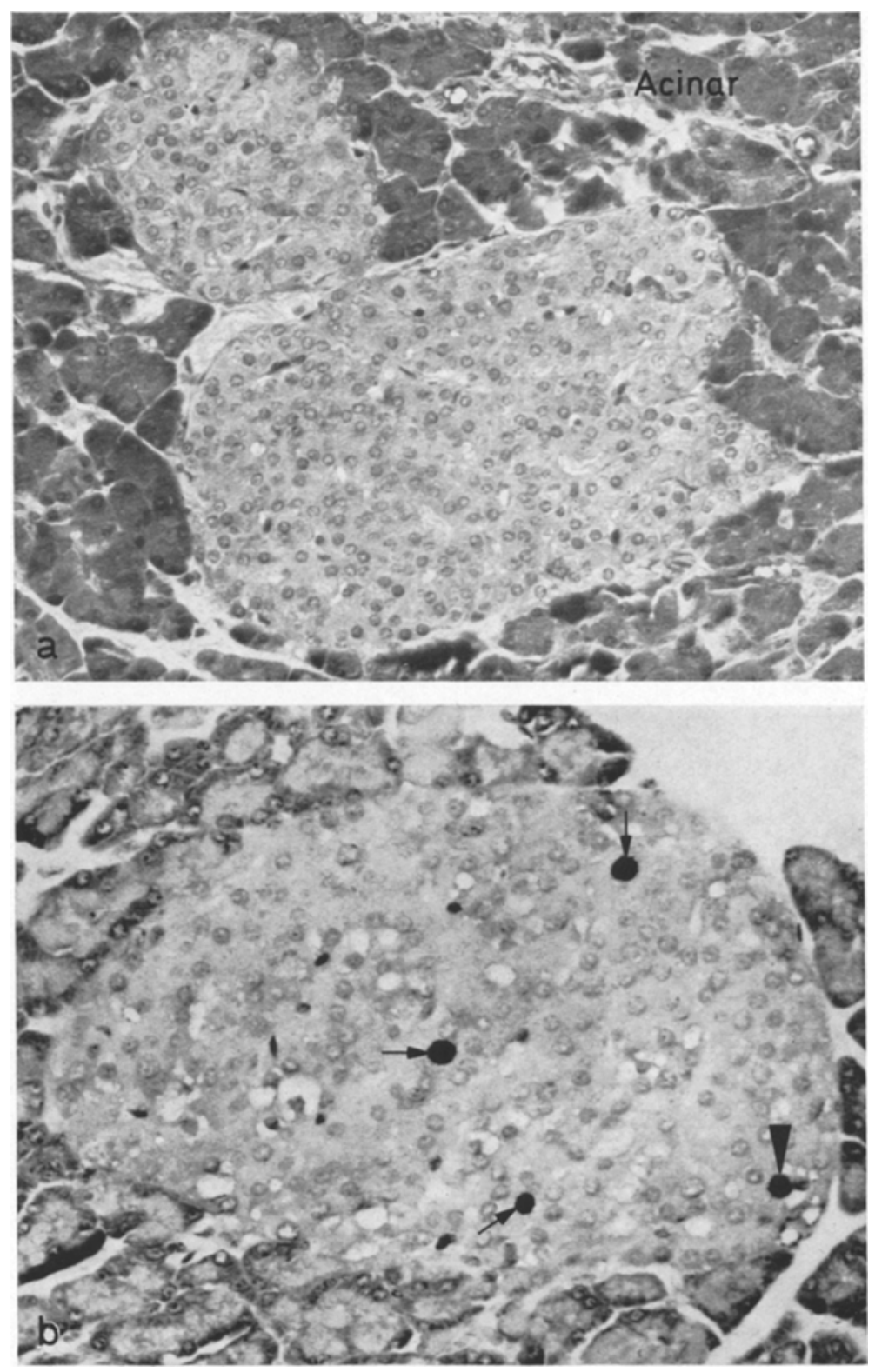

Fig. 3a and b. Pancreatic islets of normal Chinese hamster treated with glucocorticoids with resulting hyperglycemia. a) Aldehyde fuchsin stained paraffin section. Enlarged islets consist almost entirely of degranulated beta cells. Approximately $244 \times$. b) Autoradiograph after thymidine- ${ }^{3} \mathrm{H}$ injection. Nuclei of 4 beta cells are labelled. The arrow head indicates labelled cell with vacuolated cytoplasm. That the labelled nuclei belong to beta cells is suggested by the location within islet interior (arrows) and the presence of cytoplasmic vacuoles (arrow head) due to dissolved glycogen. PAS - Approximately $294 \times$ 
silver grains identify the paths of beta particles originating in DNA synthesized at the time of thymidine- ${ }^{3} \mathrm{H}$ injection which pass into and expose the overlying photographic emulsion. To verify the successful introduction of thymidine- ${ }^{3} \mathrm{H}$ into the thymidine pool of the hamster, the presence of heavily labelled duodenal crypt cells and of labelled lymphocytes within pancreatic lymph nodes was required.

\begin{tabular}{llc}
\hline & \multicolumn{2}{l}{$\begin{array}{l}\text { Number of Animals with } \\
\text { Increased Beta cell labelling }\end{array}$} \\
\cline { 2 - 3 } & Control & Treated \\
\hline Normal & $0 / 3$ & $11 / 16$ \\
Recent onset & $2 / 2$ & $2 / 3$ \\
Non-ketotic & $0 / 3$ & $0 / 6$ \\
Ketotic & $0 / 1$ & $0 / 1$ \\
Erratic & $0 / 2$ & $1 / 2$ \\
Remission & $0 / 1$ & $1 / 2$ \\
\hline
\end{tabular}

Fig. 4. Glucocorticoid induced beta cell replication in Chinese hamsters. Untreated normal pancreata contained 1-3 labelled islet cells/section. Animals with increased labelling revealed a $2-8$ fold increase (see text) increased in hamsters with long term diabetes including those with an erratic syndrome and those in remission (Fig. 4).

\section{Glucocorticoid Injected Hamsters}

Normal Hamsters. The number of labelled islet cells was increased in 11 of 16 injected non-diabetic animals. A 2-8 fold increase was estimated and the labelled nuclei appeared to be randomly by located within individual islets (Fig. 3b). Although the frequency of labelling among acinar and ductal cells appeared also to have increased, there was no apparent localization of these labelled cells and specifically no affinity for the periphery of the islets.

Diabetic Hamsters. The number of labelled islet cells was increased only in one erratic syndrome animal and one in remission, but in each group only two hamsters were available for study. Among the other groups of injected diabetic hamsters there was no change in the number of labelled islet cells (Figs. $4,5)$.

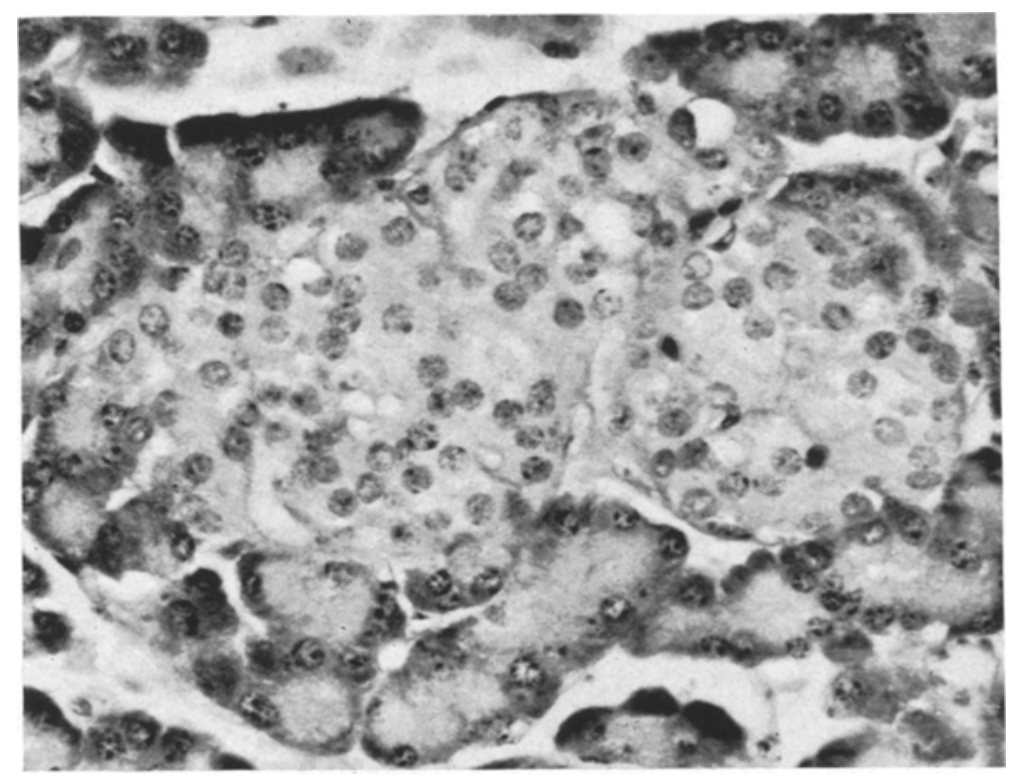

Fig. 5. Pancreatic islet of glucocorticoid treated nonketotic hamster. Autoradiograph after thymidine- ${ }^{3} \mathrm{H}$ injection. Islet cells are not labelled. PAS Approximately $460 \times$

Normal Hamsters. Labelled islet cells were identified with great difficulty in untreated normal animals. Random sections of an entire pancreas in which $7-23$ islets were observed contained at most $1-3$ labelled islet cells. Labelled exocrine and connective tissue cells were observed more frequently but were also uncommon.

Diabetic Hamsters. The incidence of labelled islet cells was increased only among the recent onset diabetics. Although the increase was moderate $(4-5 \times$ normal) it was observed in both hamsters studied. In contrast, the number of labelled islet cells was not

\section{Discussion}

\section{Normal Hamsters}

The results reported above indicate that the nondiabetic Chinese hamsters are similar to other laboratory rodents in regard to the structure and function of their pancreatic islets. Factors considered include islet size, disposition of alpha and beta cells, the abundance of aldehyde fuchsin positive granules within the beta cells and the minimal number of islet cells labelled after a single injection of thymidine- ${ }^{3} \mathrm{H}[12,30]$. The results indicate also that normal 
hamsters bred from parental lines that have been consistently aglycosuric for many generations will have normal blood glucose, plasma IRI levels and an $\mathrm{I} / \mathrm{G}$ ratio of approximately 2.0 .

\section{Diabetic Hamsters}

Early after the onset of hyperglycemia, the islets of recent onset diabetic hamsters are moderately increased in size, contain enlarged and partially degranulated beta cells, and increased numbers of labelled islet cells. Plasma IRI and BG are both increased and the $\mathrm{I} / \mathrm{G}$ ratio is maintained. These results suggest that beta cells of diabetic Chinese hamsters possess the ability, at least for a limited period of time, to synthesize increased quantities of IRI, as well as the potential for enhanced cell replication presumably in response to elevated levels of $B G$ $[30,31]$. With progression of the diabetic syndrome, plasma levels of IRI decline in the face of continued hyperglycemia. The dramatic reduction of the $I / G$ ratio among non-ketotic and especially ketotic hamsters emphasizes the loss of insulin synthetic capacity and correlates well with evidence of decreasing beta cell numbers and failure of beta cell replication. The occurrence of a reduction in beta cell numbers was supported by the observation of cell necrosis by electron microscopy $[9,10,25]$, the presence of alpha cells within the interior of the islet, and foci of islet fibrosis.

In contrast, the elevated plasma IRI, the reduction of $\mathrm{BG}$ and the elevated $\mathrm{I} / \mathrm{G}$ ratio indicate that hamsters in remission have regained sufficient insulin synthetic capacity to normalize glucose-insulin homeostasis. The presence of enlarged islets containing greater numbers of beta cells, in the absence of increased labelling, suggests that beta cell replication had already occurred prior to the time of thymidine- ${ }^{3} \mathrm{H}$ injection and had adequately compensated for the decrease in number due to necrosis.

There is no satisfactory explanation for the unpredictable physiological data that characterize the diabetic syndrome of erratic syndrome hamsters. The findings reported above do not support our prediction that these animals would have an increased beta cell mass and enhanced insulin synthesis. In fact the $B G$, IRI, I/G ratio and islet histology of the erratic syndrome and non-ketotic hamsters cannot be distinguished. In view of the known heterogeneity of the erratic syndrome and non-ketotic groups of hamsters, additional physiological and morphological data is required from a larger number of these animals if meaningful conclusions are to be formulated.

\section{Glucocorticoid Injected Hamsters}

The findings reported above confirm earlier reports $[23,24]$ that glucocorticoid administration induces hyperglycemia and beta cell hyperplasia in normal Chinese hamsters. Furthermore, the substantial increase in islet cell labelling suggests that in the adult hamster as well as the mouse $[12,30]$ and sub-human primate [15], beta cell mitotic division is of significance in the genesis of beta cell hyperplasia.

The apparent absence of beta cell labelling among most of the glucocorticoid injected diabetic hamsters may be explained as follows: 1 . The genetic machinery responsible for beta cell replication and the day to day maintenance of an optimum population of pancreatic islet cells may be defective in the diabetic hamster. This defect may also be responsible for the inadequate replacement of beta cells undergoing degeneration and necrosis and the eventual decline in beta cell mass and insulin synthetic capacity; 2. Diabetic hamster beta cells may possess the same number of potential mitotic divisions as non-diabetic animals, but may exhaust this potential during the early months of hyperglycemic stress; 3 . The number of possible beta cell divisions may be greater among in remission animals. This potential may have been fulfilled in the one hamster in remission without increased label. Similarly, the hamster in remission with increased numbers of labelled cells after glucocorticoid injections may not yet have exhausted its maximum number of beta cell mitotic divisions; 4 . The erratic syndrome hamster with glucocorticoid induced increased label lends support to the conviction that heterogeneity may exist among non-ketotic and erratic syndrome hamsters as a result of differing beta cell replicative capacities.

Finally, the preliminary nature of this experiment must be emphasized, as well as the fact that greater numbers of animals will be required to determine whether the frequency of beta cell labelling after glucocorticoid administration can be correlated with the severity of the genetic diabetic syndrome.

Acknowledgement. The authors wish to acknowledge with appreciation the skillful technical assistance of Mr. Douglas Hylan, Mr. Kenneth Andrews, and Mrs. Margaret Blanks.

\section{References}

1. Meier, H., Yerganian, G.A.: Spontaneous diabetes mellitus in the Chinese hamster (Cricetulus griseus). I. Pathological findings. Proc. Soc. exp. Biol. 100, $810-815$ (1959)

2. Yerganian, G.A.: Spontaneous diabetes in the Chinese hamster Cricetulus griseus. IV. Genetic aspects. CIBA Foundation Colloquia on Endocrinology 15, 25-48 (1964)

3. Butler, L.: The inheritance of diabetes in the Chinese hamster. Diabetologia 3, 124-129 (1967)

4. Gerritsen, G.C., Blanks, M. C.: Preliminary studies on food and water consumption of prediabetic Chinese hamsters. Diabetologia 6, 177-179 (1970)

5. Gerritsen, G.C., Dulin, W. E. : Effect of diet restriction on onset of development of diabetes in prediabetic Chinese hamsters. Acta diabetol. lat. 9, (Suppl. 1) $597-613(1972)$

6. Chang, A. Y., Schneider, D. I.: Rate of gluconeogenesis and levels of gluconeogenic enzymes in liver and kidney of diabetic and normal Chinese hamsters. Biochim. biophys. Acta (Amst.) 222, 587 — 592 (1970) 
7. Gerritsen, G.C., Dulin, W.E.: Characterization of diabetes in the Chinese hamsters. Diabetologia 3, $74-84(1967)$

8. Carpenter, A.M., Gerritsen, G.C., Dulin, W.E., Lazarow, A.: Islet and beta cell volumes in diabetic Chinese hamsters and their nondiabetic siblings. Diabetologia 3, 92-96 (1967)

9. Luse, S.A., Caramia, F., Gerritsen, G.C., Dulin, W.E. Spontaneous diabetes mellitus in the Chinese hamster: An electron microscopic study of the islets of Langerhans. Diabetologia 3, 97-108 (1967)

10. Boquist, L.: Pancreatic islet morphology in diabetic Chinese hamsters. A light and electron microscopio study. Acta path. microbiol. scand. 75, 399-414 (1969)

11. Orci, L., Stauffacher, W., Dulin, W.E., Renold, A.E., Rouiller, Ch.: Ultrastructural changes in A-cells exposed to diabetic hyperglycemia. Observations made on pancreas of Chinese hamsters. Diabetologia 6, $199-206(1970)$

12. Like, A.A., Chick, W.L.: Studies in the diabetic mutant mouse. I. Light microscopy and autoradiography of pancreatic islets. Diabetologia 6, 207-215 (1970)

13. Like, A.A., Chick, W.L.: Studies in the diabetic mutant mouse. II. Electron microscopy of pancreatic islets. Diabetologia 6, 216-242 (1970)

14. Chick, W.L., Like, A.A.: Studies in the diabetic mutant mouse. IV. DBM, a modified diabetic mutant produced by out-crossing of the original strain. Diabetologia 6, 252-256 (1970)

15. Like, A.A., Chick, W.L.: Pancreatic beta cell replication induced by glucocorticoids in subhuman primates. Amer. J. Path. 75, 329-348 (1974)

16. Hummel, K.P., Dickie, M.M., Coleman, D.L.: Diabetes, a new mutation in the mouse. Science 153, $1127-1128(1966)$

17. Coleman, D.L., Hummel, K.P.: Studies with the mutation, diabetes in the mouse. Diabetologia $\mathbf{3}$, $238-248$ (1967)

18. Bleisch, V.R., Mayer, J., Dickie, M.M.: Familial diabetes mellitus in mice associated with insulin resistance, obesity and hyperplasia of the islets of Langerhans. Amer. J. Path. 28, 369-385 (1952)

19. Coleman, D.L., Hummel, K.P.: The influence of genetic background on the expression of the obese (ob) gene in the mouse. Diabetologia 9, 287-293 (1973)

20. Jones, E.E.: Spontaneous hyperplasia of the pancreatic islets associated with glycosuria in hybrid mice. In: Structure and metabolism of the pancreatic islets. (Brolin, S.E., Hellman, B., Knutson, H., eds.) pp. 189-191. Oxford: Pergamon Press 1964

21. Like, A.A., Jones, E.E.: Studies on experimental diabetes in the Wellesley Hybrid Mouse. IV. Morphologic changes in islet tissue. Diabetologia 3, 179-187 (1967)

22. Lazarus, S.S., Volk, B.W.: The pancreas in human and experimental diabetes, Chapter 11. New York: Grune and Stratton 1962

23. Campbell, J., Rastogi, K.S., Hausler, H.R.: Hyperinsulinemia with diabetes induced by cortisone, and the influence of growth hormone in the Chinese hamster. Endocrinology 79, 749-756 (1966)

24. Frenkel, J.K.: Dissecting aneurysms of the aorta, and pancreatic islet cell hyperplasia with diabetes in corticosteroid and chlorothiazide treated hamsters. Progr. exp. Tumor Res. (Basel) 16, 300-324 (1972)

25. Like, A.A., Dulin, W.E., Gerritsen, G.C.: Studies in the diabetic Chinese hamster: Electron microscopy of pancreatic islets. Diabetologia 10, 509-520 (1974)

26. Hoffman, W.S.: A rapid photoelectric method for the determination of glucose in blood and urine. J. biol. Chem. 120, 51-55 (1937)

27. Zaharko, D.S., Beck, L.V.: Studies of a simplified plasma insulin immunoassay using cellulose powder. Diabetes 17, 444-457 (1968)

28. Warren, S., LeCompte, P.M., Legg, M.A.: The pathology of diabetes mellitus. 4th ed. p. 504. Philadelphia: Lea \& Febiger 1966

29. Levene, C., Feng, P.: Critical staining of pancreatic alpha granules with phosphotungstic acid hematoxylin. Stain Technol. 39, 39-44 (1964)

30. Logothetopoulos, J., Bell, E.G.: Histological and autoradiographic studies of the islets of mice injected with insulin antibody. Diabetes 15, 205-211 (1966)

31. Chick, W.L., Like, A.A.: Studies in the diabetic mutant mouse: III. Physiological factors associated with alterations in beta cell proliferation. Diabetologia 6, $243-251(1970)$

Dr. A.A. Like

Elliott P. Joslin Research Laboratory

Joslin Diabetes Foundation, Inc.,

Dept. of Pathology

Peter Bent Brigham Hospital

Harvard Medical School

Boston, Mass.

USA 